How to Cite

Atechi, S. (2018). Deceptive similarities between British English and Cameroon Pidgin English: A lexico-semantic

investigation. International Journal of Humanities, Literature \& Arts, 1(1), 11-24. https://doi.org/10.31295/ijhla.v1n1.29

\title{
Deceptive similarities between British English and Cameroon Pidgin English: A lexico-semantic investigation
}

\author{
Samuel Atechi \\ University of Yaounde I/TU Chemnitz. \\ Email: atechisammyn@yahoo.com
}

\begin{abstract}
It has now been clearly established that although the English Language is the highest donor of words to $C P E$, most of these words have undergone some changes in their meanings. This may equally imply that perhaps the meanings of some words from other sources have developed some changes. The probability of this being true is very high considering the fact that PE is the most widely used lingua franca in Cameroon and this, not withstanding, PE has not been standardized, neither has it been codified. But, one thing remains very clear that in the case of a codification, the various alterations which exist in CPE must be accommodated to a certain extend. The data so far examined are items that mostly feature in the speeches of typical users of CPE. As mentioned above, some of these users are quite conscious of these variations and as such, they sometimes (in certain milieus) avoid some of them. The result is the Anglicization of PE which of course narrows the degree of intelligibility between these users and some classes of people.

Keywords---British English, Cameroon Pidgin English, deceptive similarities.
\end{abstract}

\section{Introduction}

Cameroon Pidgin English (CPE) is one of the languages of wider communication in Cameroon, a country second only to Papua New Guinea in terms of its multiplicity of languages for a relatively small population (Todd, 2008). CPE is used side by side other languages like English and French (official languages), Fulfulde, Arab Choa, Ewondo and Duala (lingua francas), and over 250 indigenous languages. What is, however, peculiar about CPE is that it is not restricted to a particular class of people or to people from a particular region. As Mbassi-Manga (1976) asserts, it is a language that "links, at least potentially, Cameroonians from different language groups either educated in French or in English only, or non-educated at all in either of these Received Languages". This has led to a significant increase in the functional load of CPE as it is generally used in both in-group and out-of-group communication in the country. CPE is also a language of intimacy and solidarity especially in domains such as buying and selling, religious teaching and worship and cultural expressions (Menang, 2006).

Cameroon Pidgin English is a contact language and has as donor languages: the English language, French, Portuguese and Cameroonian home languages. This is as a result of various historical contacts and economic interactions with these languages. CPE has a large stock of words from the English language as opposed to other lexifiers such as Portuguese that can count only a handful of words left in the language. This is an indication that CPE is strongly tilted towards the English language. In fact, Mbangwana (1983), intimates that about $60 \%$ of lexical items used in CPE are from the English language. Thus, English language is the status language to CPE and both have their merits and demerits with regard to the way they are used in Cameroon. Though these two languages share more similarities especially at the lexical level as noted by Mbangwana, it should be abundantly clear that CPE is a language in its own right. Those who seem to see no neat line between the two must have neglected the abundant literature on CPE which demonstrates that there are systematic features at every level of its analysis that set it clearly aside from its status language, English.

The confusion is most evident at the level of the lexis, where most of the words used in British English are also used in CPE. This gives the false impression that the two languages are the same and as such there is no need to

ISSN 2632-9441

Received Jan 10, 2018 / Accepted Jun 20, 2018 / Published Jul 05, 2018 
spend time working on the two as if they were different languages. The words may be clearly English in form but when put in context, may express sheds of meaning that are quite different from what obtains in the donor language. This paper aims to show that although the words used in British English and CPE look alike in form, the meaning in CPE has drifted somehow from what is conceptually recognised in British English usage. It goes further to give reasons for this phenomenon. These changes, though sometimes baffling, are not unexpected. As Gibson et al., (1993), succinctly put it "If a word always stood for only one thing and only one idea, communication will be easy indeed; but words have a way of acquiring many meanings through their use by different people at different places, under different conditions". Hence, these English words that have moved to another language, CPE have undergone some semantic adjustments to fit the new linguistic context. Even when the context seems to be in consonance with British English usage, the word may not be used in its entirety considering that as a Pidgin, the simplification process may also involve a reduction in the number of meanings obtained by a single lexeme.

With the growing popularity of CPE assuming more functions and statuses in Cameroon, it will just be normal and timely to start investigations of this nature, which clearly distinguish the language from its main donor. This will serve as a giant step in the struggle to come up with a dictionary for CPE usage, as it asserts itself as one of the key players in the complex linguistic make-up of Cameroon.

\section{Background on Pidgin English in Cameroon}

Throughout the course of geographic history, exploration and trade have caused various populations of people to come into contact with each other. Because these people were of different cultures and thus spoke different languages, communication was often difficult. Over the decades though, languages changed to reflect such interactions and groups sometimes developed pidgins. CPE developed in this way, out of sporadic contact between Cameroonians and European traders at the coast. History has it that the first contact was with Portuguese traders but because English privateers were employed in huge numbers in Portuguese boats (Mbassi-Manga; 1973), this affected the type of Pidgin spoken in Cameroon, that is, from a Portuguese-based Pidgin to an English-based Pidgin, as majority of the lexical items in this contact language drifted gradually from Portuguese to English. To reinforce this English domination, the British through the missionaries created some schools in the territory, which paved the way for the formal learning of English. However, given the limited number of schools, very few Cameroonians could afford formal instruction in Standard English. This scenario favoured the spread of CPE to the detriment of Standard English with people borrowing extensively from English to facilitate communication, thus the growth and expansion of Pidgin English in the country and by the time English finally implanted itself, PE had made serious in-roots in the country, this time not just being used out of communicative necessity but as a language of intimacy, social interaction, etc.

The coexistence of English and Pidgin English in the complex linguistic landscape of Cameroon for so many years and the way the language is evolving has raised a number of concerns. One of the recent debates on the relationship between English and CPE is that some kind of restructuring is going on in the language which makes it to move more and more towards its status language English (Sala \& Ngefac 2006). It is claimed that this recent phenomenon is due to the fact that more and more Cameroonians are being exposed to English as compared to the 1960s when formal education in English was scarce. The prediction made as a result of this observation is that CPE and English will in the long run merge, with CPE losing its identity and idiosyncrasies. I follow Sala and Ngefac, as any other keen observer of the evolution of CPE, that there is some restructuring taking place in CPE of late, and that this evolution shows an upward movement towards Standard English. That this restructuring is attributed to the increase in the level of education of Cameroonians, the media and globalisation which has exposed Cameroonians to more English, is also not open to any debate. But to see this as a problem and a threat to the hegemony of CPE, is where we disagree, if not sharply. Change is a natural linguistic phenomenon. Yesterday, CPE was used more as a lingua franca, a link language between people who spoke mutually unintelligible languages, by mostly the uneducated who worked in the plantations. In short, CPE was used out of desperate communicative necessity. Today the level of education of Cameroonians has significantly increased and most of the uneducated people are giving way to the younger generation who now must speak the form of Pidgin English that reflects their level of exposure to English. What most people fail to know is the fact that CPE has along the line acquired other very significant functions that have even relegated the desperation factor to the background. That is, CPE is now the language of intimacy, social interaction, buying and selling, political discourse, etc. Thus the people who use the restructured version of $\mathrm{CPE}$, that is, the younger generation, are no longer using it out of communicative necessity. They love the language, they feel at ease with it, it is like the air they breathe. That is why I beg to differ with the prophesy that CPE is depidginising or is facing death (Schroder, 2003; Kouega, 2001; Sala \& Ngefac, 2006). In the contrary, 
Standard English is facing death as CPE has now squatted in domain that were hitherto the preserve of Standard English (Simo Bobda \& Wolf, 2003; Chia, 2009; Simo Bobda, 2009). The questions I may pose are- How can Pidgin English be facing death or depidginising when more and more youths tend to see it as a fashionable medium of communication? How can English be threatening the hegemony of CPE when CPE is giving heads of academic institutions, both private and government, sleepless nights and they look for ways of stopping its unprecedented spread into domains they thought were the preserve of English? Many of them think that CPE militates against the proper acquisition of English in manifold ways. How can CPE be facing death or is about to lose its identity and idiosyncrasies when even at the tertiary level of education in this country, the language is on the rampage as it is unseating Standard English in its function as the language of academic discourse? Threatening and sometimes desperate statements on the following signboards in the pure Anglo-Saxon university of Buea, Cameroon testify to the fact that the threat posed by CPE can only be compared to a tsunami.

a) No Pidgin on Campus please!

b) Pidgin is taking a heavy toll on your English; shun it.

c) The medium of studies at UB is English, not Pidgin

d) If you speak Pidgin, you will write Pidgin.

e) English is the password, not Pidgin

f) Speak less pidgin and more English

g) Commonwealth (people) speak English, not Pidgin.

h) Be my friend, speak English.

i) Succeed at UB by avoiding Pidgin on Campus

j) The better you speak Pidgin, the worse you will write English

Inscriptions of this nature are conspicuous in many public and private higher institutions while other private and government-owned schools have outrightly banned its use in the school premises. Simo Bobda (2009) contends that gone are the days that CPE used to considered a "canker worm" and "an impediment to logical thinking", and that today we are gradually moving to another extreme where Pidgin English, even in university circles, has squatted into domains which were hitherto the preserve of English. He further observes that "while English is fast becoming a foreign language (in the ELT sense of the term with all the consequences), Pidgin English is commonly used by postgraduate students to discuss Shakespeare and Chomsky, or Nuclear Physics". To further reinforce Simo Bobda's observation, Chia (2009) after a thorough investigation of the use of Pidgin in the University of Buea, concludes, "the fear here is that since CPE is making in-roots into the fief of Standard English in this nascent role as a language of academic discourse, it may eventually supplant Standard English". These are fresh statements founded on empirical evidence, made by linguists who have watched CPE evolve from the 1960s. It is, therefore a bit difficult to understand how the same CPE we are talking about here can be facing death or about losing its identity. It may be safely assumed that it is because the variety of CPE that is most heard now is the youth variety which has a predilection towards English especially at the lexical level, that has made people to think that this type of evolution can only militate against the continuous growth of CPE. This controversial situation calls for diligence as a keen look at the way the borrowed items are used in CPE reveals by far more than what is seen at the surface. The borrowed words undergo some semantic adjustments to suit the linguistic contexts in which they are used as we shall see in this study.

\section{Research Methods}

The data for this study was collected from youths (both students and those involved in petit trading, woodwork, car repairs, etc), and other Cameroonians of all walks of life in the Yaounde municipality. I did not discriminate the population of the study as the selection of informants was random. However, more data came from the youths given that present trends show that CPE is gradually moving towards English because the users too are changing from the older generation to a more youthful one. The data were collected by means of tape-recordings and observation.

A considerable amount of the data was collected through observation. Since the inception of this paper, every minute of discussion with people, was an occasion to collect lexical items that are used for the study. I equally used my students ${ }^{1}$ who lived and spoke Pidgin English with their friends to secretly record their conversations. Some of the data were equally tape-recorded from Pidgin English programmes over the media, such as Pidgin News and Cocoricho News.

${ }^{1}$ I am indebted to Bobdinga Randolph who helped in the collection of some of the data. 
The words identified in the data as pure English words were selected and analyzed both in English and in CPE from a lexico-semantic perspective. It was, however, discovered that most of the words used by the older generation did not exhibit the type of similarities the ones from the younger generation generated. In the process of analysing the words, it was discovered that some of the words used by the youths, especially those in Bonamoussadi (a student residential area in the metropolitan town of Yaounde), were too specialized and thus more of slang than typical Pidgin English usage. As Mbangwana (2006) observes, some of these "linguistic inventiveness delights in virtuosity for the sheer fun of it". The use of these new forms thus becomes an indication of "belonging". There is therefore a conscious or unconscious deconstruction of the English Language. I was careful not to include these in the corpus, although they will eventually spread and get integrated into the language. There are clear indications that this is already happening as most of the words were quite recurrent in the data.

This study is based on Crystal's (1995) model of describing semantic change. This model establishes six major criteria for the description of any change in the meaning of a word. The present study focuses on the meanings of lexemes in CPE and in Standard English. The meaning of a word depends upon the conventional sense the users of that word have given the word. The word is therefore what Saussure refers to as the signifier while what the word stands for is the signified. As Saussure rightly points out, the relationship between the signifier and the signified is arbitrary; that is, the relationship between, say the word book and the thing in the physical world, is not logical. This is to say there is nothing in the form of the word book that bears any direct relationship to the entity it signifies. As such, the meaning of a lexeme depends upon the acceptability of the word by users of the said word in a particular environment. Bloomfield (1933) states that the meaning of a lexeme can be deduced solely from the situation in which speech is used. Lyons (1981) quotes Wittgenstein who says "the meaning of a word is its use in the language". This implies that the meaning of a word is not static. As Lyons (ibid) points out "most everyday words do not have a single clear cut meaning or even a set of meanings" (p.138). However, this variation in meaning does not imply that we do not have certain words in a particular language which stand for something specific (in the conventional sense of the word). In this light, Bloomfield (ibid) thinks defining meaning is easier when referring to concrete things as he says:

We can define the meaning of a speech-form accurately when this meaning has to do with some matter of which we possess scientific knowledge. We can define the names of minerals, for example, in terms of chemistry and mineralogy, as when we say that the ordinary meaning of the English word salt is sodium chloride (NaCl); and we can define the names of plants or animals by means of the technical terms of botany or zoology, but we have no precise way of defining words like love or hate which concern situations that have not been accurately classified. (p. 139).

From this, it is evident that the meaning of an expression can be obtained by bringing both the verificationist and the mentalist theories together. The verificationist theory of meaning has to do with what an expression refers to outside a linguistic context, that is, in the physical world. The verifiability of the meaning of a lexeme will relate the lexeme to a concrete noun while the verifiability of a sentence or a proposition will depend upon the truth values of the said proposition. The meanings of abstract words will as such be properly handled by the mentalistic or ideational theory. Here, the meaning of an expression is the concept or idea that is associated with the expression in the minds of users of the said expression. This definition varies from one group of people to another, which makes language very arbitrary. The arbitrariness of language makes meaning to vary greatly within both linguistic and non-linguistic context. Geoffrey Leech (1975), distinguishes seven types of meaning namely Conceptual meaning, Connotative meaning, Stylistic meaning, Affective meaning, Reflected meaning, Collocative meaning and Thematic meaning. From this classification, it is evident that stylistic, reflected and affective meanings fall under connotative meaning which is also known as associative meaning. Semantics thus covers a wide range of meanings. But these meanings are intricately linked to the conceptual meaning, which is otherwise referred to as the cognitive, logical or denotative meaning. Thus, an evaluation of semantic change is in reference to the conceptual meaning.

The traditional studies of semantic change have had to do with the various ways by which we can evaluate semantic change from a synchronic perspective (Banjo, 1997; Tabufor, 1997; Odumuh, 1984; Mbouya, 2000; Igboanusi, 2003; Anchimbe, 2005; Nchwenwi, 2006; Atechi 2006). The above-mentioned researchers have succeeded in showing how the meanings of words change in a particular time in use. However, the present study is different in the sense that it examines semantic change not in a mainstream variety of English, but how loanwords from English take up new sheds of meaning in CPE. Another point of divergence is that most of the above-mentioned researchers focus on three types of changes; that is, Extension, Narrowing and Shift. This paper examines and describes six types of change with clear demonstration of how one meaning is different from the other, semantic extension, semantic shift, semantic amelioration, semantic pejoration, semantic deterioration and figurative meaning. The work equally provides elaborate reasons for the occurrence of these changes, which support the fact that the 
phenomenon of semantic change is a natural linguistic reality. The table is partitioned into five columns: column one provides the lexemes, columns two contains the part of speech as used in British English, columns three gives the British English meaning of the lexemes, columns four gives the word class of the lexemes as used in CPE while column five provides the meanings of the lexemes as used in the CPE. The only exception to this partitioning is in the presentation of figurative change in which a sixth column has been added to describe the kind of figurative change.

\section{Results and Analysis}

\section{Semantic Extension}

The meaning of a word is widened (Bloomfield, 1993). That is, a word that, at one point in time, applied only to something specific, eventually develops a new meaning or meanings. The original meaning of the word remains but other meanings are added to the word (Malmkjaer, 2004). The new meaning either moves from describing a part to describing a whole, or from describing a single entity to describing more than one entity. Crystal (1995) cites the example of virtue which at one point in time was applied only to the male sex; but which applies to both sexes in current usage. Radford et al., (1999) prefer the term broadening in the description of such a change. They advance the example of companion (a French loan) which once meant "someone who eats bread with another" as indicated by its two principal morphemes com (French-with) and pain (French bread). The meaning of the word has been broadened to incorporate "someone who goes with or spends much time with another".

The kind of semantic extension that is examined in this paper is somehow different. This paper shows how the meaning of a particular word in BrE has been extended in CPE. This ties with Zuengler's (1982) definition of semantic extension. He says it is the process of adding a new meaning or new meanings to a Standard English word.

Table 1

Extension in C PE

\begin{tabular}{|c|c|c|c|c|}
\hline Word & WC & StE Meaning & WC & CPE Meaning \\
\hline \multirow[t]{3}{*}{ Member } & $\mathrm{N}$ & Part of a group or a whole & $\mathrm{N}$ & -Same in StE \\
\hline & & & $\mathrm{V}$ & -Remember \\
\hline & & & Adj & -Being proud \\
\hline \multirow{2}{*}{ Follow } & V & Come after sth or sb & $\mathrm{V}$ & -Same in StE \\
\hline & & & Adj & -Having a love affair with sb \\
\hline \multirow[t]{2}{*}{ Chew } & V & Grind food in the mouth & V & -Same in StE \\
\hline & & & Adj & -Frown or get extremely serious \\
\hline \multirow[t]{2}{*}{ Honey } & $\mathrm{N}$ & -Sweet substance produced by bees & $\mathrm{N}$ & -Same in StE \\
\hline & & & $\mathrm{N}$ & -Bees \\
\hline \multirow[t]{2}{*}{ Neck } & $\mathrm{N}$ & Part of the body & $\mathrm{N}$ & -Same in StE \\
\hline & & & $\mathrm{N}$ & - greed \\
\hline Fever & $\mathrm{N}$ & Having abnormal high temperature & $\mathrm{N}$ & $\begin{array}{l}\text {-Same in StE } \\
\text {-Be like or similar to sb or sth }\end{array}$ \\
\hline $\begin{array}{l}\text { God } \\
\text { father }\end{array}$ & $\mathrm{N}$ & $\begin{array}{l}\text { Person who promises to see that a child is } \\
\text { brought up as a Christian when the child } \\
\text { is being baptized }\end{array}$ & $\mathrm{N}$ & $\begin{array}{l}\text {-Same in StE } \\
\text {-An influential person who sees that his } \\
\text { protégés are better placed in a society }\end{array}$ \\
\hline Army & $\mathrm{N}$ & Group of soldiers & $\mathrm{N}$ & $\begin{array}{l}\text {-Same in StE } \\
\text {-A soldier }\end{array}$ \\
\hline \multirow[t]{2}{*}{ Dry } & $\operatorname{Adj}$ & -Without moisture & Adj & -Same in StE \\
\hline & V & -Make sth to become dry & $\begin{array}{l}\text { V } \\
\text { Adj }\end{array}$ & $\begin{array}{l}\text {-Same in StE } \\
\text {-Not having much flesh (thin) } \\
\text {-Scanty }\end{array}$ \\
\hline \multirow[t]{3}{*}{ Try } & V & Make an attempt to do or get sth & $\mathrm{V}$ & -Same in StE \\
\hline & & An act of attempting sth & $\mathrm{N}$ & -Same in StE \\
\hline & $\mathrm{N}$ & & V & -Tempt sb \\
\hline \multirow[t]{2}{*}{ Die } & V & Put an end to life & V & -Same in StE \\
\hline & & & $\mathrm{N}$ & -Funeral ceremony \\
\hline
\end{tabular}




\begin{tabular}{|c|c|c|c|c|}
\hline Belly & $\mathrm{N}$ & Part of the body & $\begin{array}{l}\mathrm{N} \\
\text { Adj }\end{array}$ & $\begin{array}{l}\text {-Same in StE } \\
\text {-State of being pregnant }\end{array}$ \\
\hline \multirow[t]{2}{*}{ Story } & $\mathrm{N}$ & A fictional narration & $\mathrm{N}$ & -Same as in StE \\
\hline & & & $\mathrm{N}$ & -News \\
\hline \multirow[t]{2}{*}{ Hear } & $\mathrm{V}$ & Perceive sounds with the ears & $\mathrm{V}$ & -Same in StE \\
\hline & $\mathrm{V}$ & Listen to sth & $\mathrm{V}$ & -Understands sth or sb feel sth \\
\hline \multirow[t]{2}{*}{ Country } & $\mathrm{N}$ & -The nation as a whole & $\mathrm{N}$ & -Same as StE \\
\hline & $\mathrm{N}$ & -Any area outside towns or cities & Adj & -Primitive behaviour or person \\
\hline Stranger & $\mathrm{N}$ & Any person you do not know & $\mathrm{N}$ & -Any visitor \\
\hline Woman & $\mathrm{N}$ & Adult female human being & $\mathrm{N}$ & $\begin{array}{l}\text {-Any female being } \\
\text {-Wife }\end{array}$ \\
\hline Man & $\mathrm{N}$ & Adult male human being & $\mathrm{N}$ & $\begin{array}{l}\text {-Any male being } \\
\text {-Husband } \\
\text {-A bottle of drink }\end{array}$ \\
\hline Hang & $\mathrm{V}$ & $\begin{array}{l}\text { Attach sth at the top so that the lower part } \\
\text { is free or loose }\end{array}$ & $\mathrm{V}$ & $\begin{array}{l}\text {-Same as StE } \\
\text {-Commit suicide }\end{array}$ \\
\hline Sister & $\mathrm{N}$ & $\begin{array}{l}\text {-A girl or woman who has the same } \\
\text { parent as another person } \\
\text {-A woman who shares an interest with } \\
\text { you. }\end{array}$ & $\mathrm{N}$ & -Used to address any intimate woman \\
\hline Borrow & $\mathrm{V}$ & $\begin{array}{l}\text { Take sth from sb with the intention of } \\
\text { returning it later }\end{array}$ & $\mathrm{V}$ & $\begin{array}{l}\text {-Same as StE } \\
\text {-Give sth to sb with the intention of } \\
\text { getting it back. }\end{array}$ \\
\hline Uncle & $\mathrm{N}$ & $\begin{array}{l}\text {-The brother of someone's father or } \\
\text { mother } \\
\text {-The husband of someone's aunt }\end{array}$ & $\mathrm{N}$ & $\begin{array}{l}\text {-Same in StE } \\
\text {-Used to address any elderly man }\end{array}$ \\
\hline Attack & $\mathrm{V}$ & $\begin{array}{l}\text { The use of violence in order to hurt or kill } \\
\mathrm{sb}\end{array}$ & $\mathrm{V}$ & $\begin{array}{l}\text {-Same as StE } \\
\text {-An act of trying to take the ball from an } \\
\text { opponent in football and other sport } \\
\text { (tackle) }\end{array}$ \\
\hline Aunty & $\mathrm{N}$ & $\begin{array}{l}\text {-The sister of someone's father or mother } \\
\text {-The wife of someone's uncle }\end{array}$ & $\mathrm{N}$ & $\begin{array}{l}\text {-Used as a title of respect to address any } \\
\text { slightly older female especially one who } \\
\text { is intimate to you. }\end{array}$ \\
\hline Cargo & $\mathrm{N}$ & Goods carried in a ship or plane & $\mathrm{N}$ & Goods in general \\
\hline
\end{tabular}

\section{Semantic Narrowing}

This semantic phenomenon also called Restriction or Specialisation, is a situation whereby the meaning of a word that once applied to things in general, becomes focused on a single thing. That is, a word that was once used in a general sense tends to have a specific meaning. To use the words of Crystal (ibid), "A word becomes more specialized in meaning" Crystal cites the example of mete (meat) which in old English, referred to food in general but which now refers only to one kind of food. Radford et al., (1999) also give the examples of girl and lust. Girl in Middle English was a young person of either sex. Lust simply meant pleasure. In current usage, these words have restricted their meanings. Girl now means a young person of the female sex while lust refers to sexual pleasure. In this paper, narrowing is examined by looking at words, which have a general sense in standard English but have developed a unique or more specialized sense in CPE.

Table 2

Semantic narrowing in CPE

\begin{tabular}{|c|c|c|c|c|}
\hline Words & Wc & StE meaning & Wc & CPE Meaning \\
\hline Wrapper & $\mathrm{N}$ & Any piece of material used for wrapping sth & $\mathrm{N}$ & A piece of cloth \\
\hline Garage & $\mathrm{N}$ & $\begin{array}{l}\text { A place where vehicles are kept and } \\
\text { repaired }\end{array}$ & $\mathrm{N}$ & A place where vehicles are repaired \\
\hline Farmer & $\mathrm{N}$ & A person who grows crops and keeps & $\mathrm{N}$ & A person who grows crops \\
\hline
\end{tabular}




\begin{tabular}{|c|c|c|c|c|}
\hline & & animals & & \\
\hline Truck & $\mathrm{N}$ & $\begin{array}{l}\text { An open lorry or wagon used for carrying } \\
\text { goods }\end{array}$ & $\mathrm{N}$ & $\begin{array}{l}\text { An open wagon that is pulled or } \\
\text { pushed }\end{array}$ \\
\hline Artist & $\mathrm{N}$ & A person who creates works of art & $\mathrm{N}$ & $\begin{array}{l}\text { A person who practices creative } \\
\text { painting }\end{array}$ \\
\hline Album & $\mathrm{N}$ & $\begin{array}{l}\text { A book where photographs, stamps etc are } \\
\text { kept }\end{array}$ & $\mathrm{N}$ & A book where pictures are kept \\
\hline Minister & $\mathrm{N}$ & $\begin{array}{l}\text { A senior member of a government } \\
\text { department or a religious order }\end{array}$ & $\mathrm{N}$ & $\begin{array}{l}\text { A person at the head of a } \\
\text { government department }\end{array}$ \\
\hline Prefect & $\mathrm{N}$ & Head of students or a local government area & $\mathrm{N}$ & student leader \\
\hline Palace & $\mathrm{N}$ & $\begin{array}{l}\text { An official house of a ruler or any large } \\
\text { impressive house }\end{array}$ & $\mathrm{N}$ & $\begin{array}{l}\text { House of a traditional } \\
\text { ruler/king/president }\end{array}$ \\
\hline Palaver & $\mathrm{N}$ & $\begin{array}{l}\text { A lot of unnecessary activity, excitement or } \\
\text { trouble }\end{array}$ & $\mathrm{N}$ & Unnecessary trouble or disturbance \\
\hline Dull & Adj & $\begin{array}{l}\text { Not interesting, not sharp, not intelligent, } \\
\text { not bright or not clear }\end{array}$ & Adj & Not intelligent \\
\hline Agency & $\mathrm{N}$ & $\begin{array}{l}\text { Any business or organization that provides } \\
\text { specialized services }\end{array}$ & $\mathrm{N}$ & $\begin{array}{l}\text { A business that handles travelling } \\
\text { matters }\end{array}$ \\
\hline Consult & $\mathrm{N}$ & Go to somebody for information or advice & $\mathrm{V}$ & $\begin{array}{l}\text { Go to a medical specialist for } \\
\text { health matters }\end{array}$ \\
\hline Discharge & $\mathrm{V}$ & $\begin{array}{l}\text { The act of releasing a substance such as gas, } \\
\text { liquid from somewhere }\end{array}$ & $\mathrm{V}$ & $\begin{array}{l}\text {-The act of releasing semen from } \\
\text { the bowels } \\
\text {-Grant sb the permission to leave } \\
\text { the hospital. }\end{array}$ \\
\hline Illiterate & Adj & $\begin{array}{l}\text { Person who does not know much about a } \\
\text { particular field of studies or who cannot } \\
\text { read and write. }\end{array}$ & Adj & Person who cannot read or write. \\
\hline Animal & $\mathrm{N}$ & $\begin{array}{l}\text { Any living creature that moves, eats and } \\
\text { breaths }\end{array}$ & $\mathrm{N}$ & $\begin{array}{l}\text { A creature which is not a fish, a } \\
\text { bird, an insect or a reptile }\end{array}$ \\
\hline Girl friend & & $\begin{array}{l}\text {-A girl or woman having a romantic } \\
\text { relationship with sb } \\
\text {-A boy or a man's female friend }\end{array}$ & $\mathrm{N}$ & $\begin{array}{l}\text { - A girl or woman that sb is having } \\
\text { a romantic relationship with }\end{array}$ \\
\hline Breakable & Adj & Sth that is likely to break or easily broken & $\mathrm{N}$ & A plate made of China clay \\
\hline Landlord & $\mathrm{N}$ & $\begin{array}{l}\text { A man from whom you rent a land or house } \\
\text { A man who owns or manages a pub or } \\
\text { guests a house }\end{array}$ & $\mathrm{N}$ & $\begin{array}{l}\text { A person whom you rent a land or } \\
\text { house from }\end{array}$ \\
\hline Product & & A thing that is grown or produced & & $\begin{array}{l}\text { A substance used to make sb's hair } \\
\text { lighter }\end{array}$ \\
\hline Society & $\mathrm{N}$ & $\begin{array}{l}\text { An organization of people having sth in } \\
\text { common or formed for a particular purpose }\end{array}$ & $\mathrm{N}$ & $\begin{array}{l}\text { An organization of people of using } \\
\text { diabolic means to make money }\end{array}$ \\
\hline
\end{tabular}

\section{Semantic Shift}

Semantic shift, as the name implies, has to do with a shift in the meaning of a word from the description of one thing to that of another. That is, a word loses it original meaning and gains a new meaning or "moves from one set of circumstances to another" (Crystal ibid: 55). In this kind of change, the outcome of the new meaning cannot be concretely explained as the relationship between the old and the new meaning cannot be reconciled. A good example of this kind of change is analysed by Radford et al., (1999) where a word like nice (a loan from Latin nescius meaning ignorant) has developed various meanings in the English Language. In the $14^{\text {th }}$ century, it meant silly or wanton, $15^{\text {th }}$ century, it meant coy or shy, $16^{\text {th }}$ century, it meant subtle, while in the $18^{\text {th }}$ century it meant agreeable or good. This information implies that the $18^{\text {th }}$ century meaning is what obtains in present day usage. The words identified under semantic shift in this paper, are words that have shifted from their StE meanings. This kind of 
semantic shift is what Zuengler (1982) defines as the "redefinition of characteristic patterns of a word within the semantic field so that it acquires a new meaning altogether different from its meaning in BrE".

Table 3

Semantic Shift in CPE

\begin{tabular}{|c|c|c|c|c|}
\hline Words & wc & $\mathrm{StE}$ & wc & CPE Meaning \\
\hline Dealer & $\mathrm{N}$ & $\begin{array}{l}\text { A person who buys and sells a particular } \\
\text { product }\end{array}$ & $\mathrm{N}$ & A person who dupes others \\
\hline Chap & $\mathrm{N}$ & $\begin{array}{l}\text { Used to talk about a man or a boy in a } \\
\text { friendly way }\end{array}$ & $\mathrm{N}$ & $\begin{array}{l}\text {-Girl friend } \\
\text {-Also used to address any young } \\
\text { girl }\end{array}$ \\
\hline Chick & $\mathrm{N}$ & A baby bird (usually a baby chicken) & $\mathrm{N}$ & -Girl friend \\
\hline Craze & $\mathrm{N}$ & An enthusiasm towards something & V & Being mad \\
\hline Claim & $\mathrm{V}$ & Demand or take responsibility over sth & Adj & Showing feelings of pride \\
\hline Villager & $\mathrm{N}$ & Someone who lives in a village & Adj & A primitive person \\
\hline Dress & $\mathrm{N}$ & Clothes & V & Shift or move away from sth or sb \\
\hline Follow-up -- & $\mathrm{N}$ & An act of continuing sth & $\mathrm{V}$ & Act of provoking sb \\
\hline Chop & V & $\begin{array}{l}\text { Cut sth into pieces with a sharp tool such as } \\
\text { an axe }\end{array}$ & $\mathrm{V}$ & Eat sth with the mouth \\
\hline Chopper & $\mathrm{N}$ & A heavy tool used in cutting sth into pieces & Adj & A spendthrift \\
\hline Mesh & $\mathrm{N}$ & $\begin{array}{l}\text { Material made of thread of plastic rope or } \\
\text { wire }\end{array}$ & $\mathrm{N}$ & Artificial hairs used for plating \\
\hline Napkin & $\mathrm{N}$ & $\begin{array}{l}\text { Piece of cloth or paper used at meals for } \\
\text { protecting clothes and cleaning lips }\end{array}$ & $\mathrm{N}$ & $\begin{array}{l}\text { Piece of soft fabric that is folded } \\
\text { round a baby's bottom to absorb } \\
\text { and hold its body waste (nappy) }\end{array}$ \\
\hline Council & $\mathrm{N}$ & A group of people elected to govern an area & $\mathrm{N}$ & $\begin{array}{l}\text { A building where councillors } \\
\text { work }\end{array}$ \\
\hline Cosh & $\mathrm{N}$ & A short thick heavy piece of metal & $\begin{array}{l}\mathrm{N} \\
\mathrm{V}\end{array}$ & $\begin{array}{l}\text {-An insult } \\
\text {-Act of insulting sb }\end{array}$ \\
\hline Yap & V & Make a high, sharp and irritating sound & $\mathrm{V}$ & Denigrate sb \\
\hline Nag & $\mathrm{V}$ & To keep disturbing or irritating sb & $\mathrm{V}$ & Beat $\mathrm{sb}$ \\
\hline Shark & $\mathrm{N}$ & Large sea fish & $\begin{array}{l}\mathrm{N} \\
\mathrm{V}\end{array}$ & $\begin{array}{l}\text { A drink } \\
\text { Act of drinking sth }\end{array}$ \\
\hline Snack & $\mathrm{N}$ & $\begin{array}{l}\text { A small amount of food usually eaten in the } \\
\text { afternoon }\end{array}$ & $\mathrm{N}$ & A lucrative drinking spot \\
\hline Yore & $\mathrm{N}$ & Long ago & Adj & $\begin{array}{l}\text { A boy or man who behaves and } \\
\text { dresses in a western way }\end{array}$ \\
\hline Dash & $\begin{array}{l}\mathrm{N} \\
\mathrm{N}\end{array}$ & $\begin{array}{l}\text { An act of going somewhere suddenly } \\
\text { A punctuation mark } \\
\text { A small amount of sth that is added to sth } \\
\text { else }\end{array}$ & $\begin{array}{l}\mathrm{N} \\
\mathrm{N}\end{array}$ & $\begin{array}{l}\text {-A gift } \\
\text {-An extra amount of sth added to } \\
\text { what has been bought }\end{array}$ \\
\hline Irish & Adj & The people and language of Ireland & $\mathrm{N}$ & A kind of potato tubers \\
\hline Jackass & $\mathrm{N}$ & A stupid person & $\mathrm{N}$ & $\begin{array}{l}\text { A person who works too much for } \\
\text { another person }\end{array}$ \\
\hline Banger & $\mathrm{N}$ & Sausage & & Marijuana \\
\hline Backside & $\mathrm{N}$ & Part of the body (bottom or buttocks) & $\mathrm{N}$ & An area behind the house \\
\hline Mannequin & $\mathrm{N}$ & $\begin{array}{l}\text {-A life-size dummy of a human body used } \\
\text { by tailors to display dresses } \\
\text {-A woman employed to display new types } \\
\text { of clothes }\end{array}$ & $\mathrm{N}$ & A slim beautiful girl or woman. \\
\hline $\begin{array}{l}\text { Bodice } \\
\text { China }\end{array}$ & $\mathrm{N}$ & $\begin{array}{l}\text { Top part of a woman's dress } \\
\text { White clay used for making delicate cups } \\
\text { plates }\end{array}$ & $\mathrm{N}$ & $\begin{array}{l}\text { Tight-fitting dress } \\
\text { Low quality good }\end{array}$ \\
\hline
\end{tabular}




\begin{tabular}{|c|c|c|c|c|}
\hline Escapee & $\mathrm{N}$ & $\begin{array}{l}\text { Sb who escapes from prison or any } \\
\text { confining institution }\end{array}$ & $\mathrm{N}$ & $\begin{array}{l}\text { A girl with so many lovers } \\
\text { (a Casanova) }\end{array}$ \\
\hline Set & $\mathrm{V}$ & Give form to sth & $\mathrm{V}$ & Frame sb up \\
\hline Caterpillar & $\mathrm{N}$ & $\begin{array}{l}\text { A small worms like creature that develops } \\
\text { into a butterfly }\end{array}$ & $\mathrm{N}$ & A bulldozer or a dumper truck \\
\hline Original & Adj & $\begin{array}{l}\text { Existing from the beginning or newly } \\
\text { created }\end{array}$ & Adj & $\begin{array}{l}\text { Solid good, usually made in } \\
\text { Europe or America }\end{array}$ \\
\hline Imitation & Adj & Sth produced as a copy of the real thing & Adj & $\begin{array}{l}\text { Sth that is not durable or sth that } \\
\text { is produced in Cameroon, Nigeria, } \\
\text { China or The United Arab Emirate } \\
\text { (Dubia) }\end{array}$ \\
\hline Local & Adj & $\begin{array}{l}\text { Belonging to a particular place or affecting } \\
\text { a particular area. }\end{array}$ & Adj & Not magnificent or extraordinary. \\
\hline Master & $\mathrm{N}$ & $\begin{array}{l}\text { Man who has people working for him or } \\
\text { person who has a specialised skill in sth. }\end{array}$ & $\mathrm{N}$ & Husband. \\
\hline Mash & V & Crush food into soft mass. & $\mathrm{V}$ & $\begin{array}{l}\text {-Trample on sb or sth } \\
\text {-Kick someone or sth. }\end{array}$ \\
\hline
\end{tabular}

\section{Semantic Amelioration}

This is a situation whereby a lexeme loses an original sense of disapproval and as such, develops a positive sense of approval. Bloomfield describes this phenomenon as Elevation. Radford et al (ibid) use the word constable which once meant an attendant at the table. The current meaning of the word has been elevated, that is, a rank in the police force. Due to the fact that the status of a police officer is overwhelmingly seen as superior to that of an attendant at table, it implies that the meaning of the word has been ameliorated or upgraded. In this paper the words I describe as having undergone the process of amelioration are words that have a sense of disapproval in $\mathrm{BrE}$ but rather have a sense of approval in CPE. Or, words that are lower in status in BrE but are of comparatively higher status in CPE or better still, are upgraded in CPE.

Table 4

Semantic Amelioration in CPE

\begin{tabular}{lclcl}
\hline Words & WC & StE meaning & WC & CPE meaning \\
\hline Ruffian & N & A violent and a lawless person. & N & A person who is not gentle. \\
Barber & N & $\begin{array}{l}\text { A person whose job is to cut men's } \\
\text { hair. }\end{array}$ & N & $\begin{array}{l}\text { A person who cuts and at times washes and } \\
\text { shapes the hairs of both men and women. }\end{array}$ \\
Terrible & Adj & Very unpleasant, and shocking. & Adj & $\begin{array}{l}\text { Also very good, striking. } \\
\text { bad }\end{array}$ \\
\hline
\end{tabular}

\section{Semantic Pejoration}

Pejoration is the direct opposite of amelioration. This is a situation where a word develops a sense of disapproval. Here, a word that previously had a favourable connotation eventually developed an unfavourable one. Words which were equally neutral eventually developed a negative connotation. Crystal (1999) and Radford et al., (1999) cite the example of villain which was formerly used to describe farm dwellers (serfs). In Modern English, villain is used to describe criminals. Another example is the word notorious. Crystal (1995) says the word once meant widely known and now, it means widely and unfavourably known. From these two examples, we notice that the word villain has shifted its meaning while notorious has maintained part of its meaning. Thus, pejoration can be a single process as in notorious or a double process as in villain. That is, a word can shift from its meaning before developing a negative connotation, or a word can maintain its basic meaning with a negative undertone. This phenomenon is also known as deterioration, downgrading and denigration.

This paper examines this semantic situation by looking at neutral words or words with favourable meaning in $\mathrm{BrE}$ and contrasting them with the same words in CPE which have developed negative meanings. Crystal (1999) hints that the choice of describing a particular kind of change as amelioration or deterioration "depends on factors that are more to do with personal taste and morality than with language" (1999: 138). 
Table 5

Semantic Pejoration in CPE

\begin{tabular}{|c|c|c|c|c|}
\hline Words & WC & StE meaning & WC & CPE meaning \\
\hline Dealer & $\mathrm{N}$ & $\begin{array}{l}\text { A person who buys and sells a } \\
\text { particular product. }\end{array}$ & $\mathrm{N}$ & A person who dupes people. \\
\hline Charm & $\mathrm{N}$ & $\begin{array}{l}\text { Feature or quality that pleases } \\
\text { people. }\end{array}$ & $\mathrm{N}$ & $\begin{array}{l}\text { A local concoction believed to have a spell } \\
\text { on a particular person. }\end{array}$ \\
\hline Wonderful & Adj & Very good, pleasing or enjoyable & Adj & $\begin{array}{l}\text { Also very unpleasant, strange and } \\
\text { frightening. }\end{array}$ \\
\hline primitive & $\operatorname{adj}$ & Original, uncontaminated, & & uncivilized \\
\hline
\end{tabular}

\section{Figurative Use}

Crystal (1995) describes this kind of change as "a shift in meaning based on an analogy or likeness between things". This kind of change can take the form of a metonymy, a metaphor, a synecdoche, hyperbole or a litotes. An example of this kind of change given by Crystal (ibid) is the word crane which is the name of a bird with a long neck. The physical appearance of the bird has led to the use of crane as a piece of equipment with a long stretch which is used for lifting goods. Bloomfield (1933) gives a number of ways by which figurative change can occur. One of which is the use of the word jaw to refer to cheek. This is a metonymy as an attribute of cheek has been used to refer to the entire cheek. It should be noted that not all types of figurative languages affect the meanings of word. This is because we have figures of speech that "extend the meaning of words (tropes) and those that merely affect their order or their impact upon an audience (schemes). The former types are those of importance to this study.

Table 6

Figurative Usage in CPE

\begin{tabular}{|c|c|c|c|c|c|}
\hline Words & $\mathrm{WC}$ & StE meaning & $\mathrm{WC}$ & CPE meaning & Figure of speech \\
\hline Satan & $\mathrm{N}$ & The devil & Adj & $\begin{array}{l}\text { Same as in StE } \\
\text {-A very wicket person }\end{array}$ & Hyperbole \\
\hline Honey & $\mathrm{N}$ & $\begin{array}{l}\text { Sweet nectar produced by } \\
\text { bees. }\end{array}$ & $\mathrm{N}$ & $\begin{array}{l}\text {-Same in StE } \\
\text {-Bees }\end{array}$ & Synecdoche \\
\hline Door & $\mathrm{N}$ & $\begin{array}{l}\text { A passage that is opened and } \\
\text { closed so that sth or sb can } \\
\text { get in and out of }\end{array}$ & & $\begin{array}{l}\text {-Same in StE } \\
\text {-The entire house of or sb's } \\
\text { room }\end{array}$ & Synecdoche \\
\hline Motor & $\mathrm{N}$ & $\begin{array}{l}\text { A device that uses petrol, gas } \\
\text { or electricity to make it work }\end{array}$ & $\mathrm{N}$ & A car & Synecdoche \\
\hline Machine & $\mathrm{N}$ & $\begin{array}{l}\text { A piece of equipment } \\
\text { designed to do a particular } \\
\text { job with the help of } \\
\text { electricity gas }\end{array}$ & $\mathrm{N}$ & $\begin{array}{l}\text {-Same in StE } \\
\text {-A road vehicle with two } \\
\text { wheels driven by an engine } \\
\text { (motor cycle) }\end{array}$ & Metonymy \\
\hline Tendon & $\mathrm{N}$ & $\begin{array}{l}\text { A strong band of tissue in } \\
\text { the body that joins a muscle } \\
\text { to a bone }\end{array}$ & & $\begin{array}{l}\text { - Same as in StE -A } \\
\text { person who is highly } \\
\text { resistant }\end{array}$ & Metaphor \\
\hline Towel & & $\begin{array}{l}\text { A piece of fabric or paper } \\
\text { used for drying things }\end{array}$ & $\mathrm{N}$ & $\begin{array}{l}\text {-Same in StE } \\
\text { - A particular type of meat }\end{array}$ & Metaphor \\
\hline Skin & & $\begin{array}{l}\text { The layer of tissue that } \\
\text { covers the body }\end{array}$ & $\mathrm{N}$ & $\begin{array}{l}\text {-The entire body of an } \\
\text { animal }\end{array}$ & Synecdoche \\
\hline Ground & $\mathrm{N}$ & $\begin{array}{l}\text { The solid surface of the } \\
\text { earth }\end{array}$ & & $\begin{array}{l}\text {-Same in StE } \\
\text {-The earth }\end{array}$ & Synecdoche \\
\hline Calabah & $\mathrm{N}$ & A large tropical fruit & & $\begin{array}{l}\text { The outer skin of this fruit } \\
\text { used as a container }\end{array}$ & Synecdoche \\
\hline
\end{tabular}


A number of factors could account for the different changes observed in the use of lexical items above. This section critically examines some of such factors.

The Low Mastery of the Lexicons of a Language: This is one of the principal causes of semantic change. This is either due to the fact that the user of the language is still a child or because the language is not the first language (L1) of the user. In the case where the user is a child, there is usually the tendency to over generalize certain usages. For example, the child may refer to any hairy animal with four legs as a dog (Todd, 1990). In the case of the latter where we have an adult speaker learning the language as second (L2) or third language (L3), the linguistic burdens of handling these languages may not be easy to cope with. As such, he/she may end up having a low mastery of the lexicons of either of the languages. This implies he will try by all possible means to express his thought using his limited vocabulary. In trying to do this, some words may be over utilized while others may be underutilized.

The Nature of some Words: Some lexemes have several meanings. These types of lexemes are generally classified as polysemic or homonymic depending on the relationship between the several meanings of a single lexeme. Having a good mastery of all the meanings of words of such nature is not easy especially to non-native speakers of a language as they may tend to use only the central meaning (relegating the derived meanings) of a polysemous word or have a knowledge on only one of the meanings of a homonymic word. This is the case with words such as fight which is used in CPE to refer only to the exchange of physical confrontation between people.

The Influence of other Languages: When languages come into contact and are obliged to co-exist in the same environment, there is the tendency for features of one language to interfere in another. This usually cuts through all the levels of language analysis although it is most noticeable at the phonological level. As for semantics, which is the focus of this paper, the presence of lexical items with similar forms (spoken or written) but different meanings in different languages may cause the users of these languages to transpose the meaning of an item in one language and use it in another. For example, the presence of French and English in Cameroon may make users of English to carry the French meanings of words such as supporter (to bear) and ignorer (to be ignorant about something) and use them in English. These types of words are referred to as false friends. Use examples from the corpus

The Avoidance of Taboo or Unpleasant Words: Some lexemes are avoided in certain contexts because they are believed to be embarrassing or offensive or their use can cause harm in certain situations. These are lexemes that dwell on issues such as sexual intercourse, death, and physical, or mental abnormality. The difficulty in using such lexemes in certain milieus leads to the use of certain words within the same language or the creation of certain expressions that sound euphemistic. In the case of the former, the different words assume new meanings, which if used continuously may become a norm. Some of the words examined under semantic extension and shift are as a result of this phenomenon. For example, we have the use of the lexeme rod to refer to penis.

Chance Error in Articulation: Even though phonological deviance, many fail to make the listener to understand exactly what is being referred to by the speaker, it can still lead the listener to something which is within the scope of the language in question. That is, if a speaker pronounces the word bird as $/ \mathrm{b} \varepsilon \mathrm{d} /$ instead of $/ \mathrm{b} 3 \mathrm{~d} /$ the fact that something like /bed/ exist in the language may in the long run make the meaning of the lexemes bird to be given to the spoken form bed. If the error is made by a group of people continuously, it eventually becomes a norm in a new variety. In this new variety, bed will either become a homonym meaning. - a piece of furniture used to sleep or rest on and a feathered animal with two wings and two legs. Or, bed and bird can eventually become homophones while maintaining their respective meanings. In the first case, the meaning of the lexeme bed has changed. This usually leads to ambiguity as a word in one accent will be perceived as quite a different word in another accent.

The Arbitrary Nature of Language: As mentioned in chapter three, the relationship between words and what the words actually represent in the physical world is not logical. Words are merely symbols that people of a particular community agree upon to represent the realities existing within the realms of the said community. This implies that any word can be used to represent anything provided it is accepted and used within the community. If for example the word cat is used to refer to an area where studied are carried out, there is nothing within the structure of a language that prohibits it from being used in that sense. Everything in language thus boils down to acceptability. This can be considered as the main reason for language change in general

Method of Acquisition: The change in the meanings of some words is due to the method through which the language is acquired. When a second language is acquired or learned from incompetent users or instructors, the errors made by these instructors will definitely features in the speech of the learners and in the long run, it may becomes a norm. Todd (1990) has advanced the nautical jargon theory to strengthen this point. The theory holds that Africans and Asians initially acquired European languages from sailors who had developed a common denominator language because they were of different linguistic background. This implies that what was passed onto Africans and Asians, were not the cream of European languages. This is also referred to as the Relexification theory. 
Cultural Inclination: The communal nature of most African societies is such that addressing an uncle as uncle or a step sister as step sister is usually regarded as a violation of some "ethical values". There is as such the extended use of names pertaining to the basic family structure; that is, father, mother, brother and sister. It is normal in most African traditional societies for somebody to address his first, second or even third cousins as brothers or sisters. Likewise, addressing your mother's sisters and friends as mother is normal. Hence, all the lexical items expressing biological relationship have witnessed an extension.

The Influence of Brand Names: Brand names have a powerful influence on the ways the realities around us are named; especially things that are foreign to us. Access to the proper names of some assets is mostly through education; usually specialised education. When this is not the case, the users resort to the labels on the assets. For example, most uneducated Cameroonians know of Molinex not Blender or Liquidizer. Likewise, Caterpillar is used instead of bulldozer. In a CPE sentence like "caterpillar dem di fix de road." The caterpillar in the sentence is not referring to a small worm-like creature, which is its appropriate name, but to bulldozers or dumper trucks which are branded as Caterpillar. Peters (2004) hints that when the brand names of a product is continuously used in placed of the product as if it's the only product of its kind in the market, the brand name of the product will eventually merit a place in a dictionary.

\section{Conclusion}

It has now been clearly established that although the English Language is the highest donor of words to CPE, most of these words have undergone some changes in their meanings. This may equally imply that perhaps the meanings of some words from other sources have developed some changes. The probability of this being true is very high considering the fact that PE is the most widely used lingua franca in Cameroon and this, not withstanding, PE has not been standardized, neither has it been codified. But, one thing remains very clear that in the case of a codification, the various alterations which exist in CPE must be accommodated to a certain extend.

The data so far examined are items that mostly feature in the speeches of typical users of CPE. As mentioned above, some of these users are quite conscious of these variations and as such, they sometimes (in certain milieus) avoid some of them. The result is the Anglicization of PE which of course narrows the degree of intelligibility between these users and some classes of people.

However, some of these changes are bound to spread to other areas and other varieties of PE. The gradual diffusion of linguistic change in general is a strong indication that even though this study is mostly based on the PE of the youths, some of the changes examined have already circulated over wider areas and have existed for a relatively longer time in use than others. Those that one can say, without much inconvenience, that are still very peculiar to the youths (as of now) are words such as chap (girlfriend) escapee (a flirt), brain (to woo a girl) and bilingual (a homosexual).These may be considered by some people as slangs; but the speed at which some of these items are spreading is indicative of the fact that they can no longer be considered as mere slangs. Seidl \& McMordie (1988) in talking on the changing attitudes towards languages, say: "several words which were considered to be slangs in the past have gradually been up-graded in status and are now considered informal or colloquial. Much of what was labelled informal in the past is now considered neutral in style".

Others like member (remember, being proud), cargo (goods) and borrow (borrow, lend) have strongly established themselves in the speech production of most (if not all users of CPE). Likewise, others such as chop (food) and stranger (visitor) have spread over national boundaries as they feature in both Nigerian and Ghanaian PE and have equally been regard as constituting some varieties of English. What this means is that some of the changes still peculiar to the PE of the youth may in future, spread not only to other varieties of PE but also to a main variety of English such as Cameroon English.

My prediction is that as Pidgin English is evolving towards the Pidgin of the youths, most of these lexical items that look specialised will form the very basis of the CPE that will now be described. Since the youths are conscious of what they are doing and know that they are using this language not out of any communicative necessity, but out of their love and affection towards the language it will be difficult to have Standard English supplant this medium that is instead making in-roots into domains hitherto the preserve of Standard English.

\section{Acknowledgements}

The author would like to thank the editor for their valuable time and advice. 


\section{References}

Ariel, M. (2008). Pragmatics and grammar. Cambridge: Cambridge University Press.

Astawa, I. N., Mantra, I. B. N., \& Widiastuti, I. A. M. S. (2017). Developing Communicative English Language Tests for Tourism Vocational High School Students. International Journal of Social Sciences and Humanities (IJSSH), 1(2), 58-64.

Atechi, S. N. (2006). The intelligibility of native and non-native English speech. Cuvillier.

Bamgboșe, A., Banjo, L. A., \& Thomas, A. (1997). New Englishes: A West African Perspective. Africa World Pr.

Bautista, L. S. (2004). An overview of the Philippine component of the International Corpus of English (ICEPHI). Asian Englishes, 7(2), 8-26.

Bloomfield, L. (1965). Language New York. Taylor \& Francis.

Bobda, A. S. (1994). Lexical innovation processes in Cameroon English. World Englishes, 13(2), 245-260.

Boko, P. G. C., \& d'Afrique, E. S. L'institut Universitaire Panafricain (IUP).

Crystal, D. (2004). The Cambridge encyclopedia of the English language. Ernst Klett Sprachen.

Crystal, D. (2004). The Cambridge encyclopedia of the English language. Ernst Klett Sprachen.

Crystal, D. (2011). A dictionary of linguistics and phonetics(Vol. 30). John Wiley \& Sons.

Fasse-Mbouya, I. (2000). English and French loans in Ngiemboon. Unpublished MA dissertation). University of Yaounde I.

Geoffrey, L. (1976). Semantics.

Gibson, K. R., Gibson, K. R., \& Ingold, T. (Eds.). (1994). Tools, language and cognition in human evolution. Cambridge University Press.

Gilman, C. (1979). Cameroonian Pidgin English, a neo-African language. Readings in creole studies, 2.

Iriani, D. H. (2018). The Effect of Early English Learning on Psychology. International Journal of Social Sciences and Humanities (IJSSH), 2(1), 65-74.

Kioko, A. N., \& Muthwii, M. J. (2003). English variety for the public domain in Kenya: Speakers' attitudes and views. Language Culture and Curriculum, 16(2), 130-145.

Korpi, W. (1983). The democratic class struggle. Routledge.

Kouega, J. P. (1999). Some major speech traits of Cameroon media news in English.

Kouega, J. P. (2007). A dictionary of Cameroon English usage(Vol. 10). Peter Lang.

Lyons, J. (1981). Language and linguistics. Cambridge University Press.

Maba, W., \& Mantra, I. B. N. (2017). An Analysis of Assessment Models Employed by The Indonesian Elementary School Teachers. International Journal of Social Sciences and Humanities (IJSSH), 1(1), 39-45.

MAIR, C. (2013). 18 Speculating on the future of English. English as a Contact Language, 314.

Malmkjær, K. (Ed.). (2009). The Routledge linguistics encyclopedia. Routledge.

Mbangwana, P. (1983). The Role and Scope of Pidgin English in Cameroon. Koenig, Edna et al.(eds.), $144-162$.

Mbangwana, P. (2004). Pidgin English in Cameroon: A veritable linguistic menu. Africa Meets Europe: Language Contact in West Africa. New York, 23-44.

Mbangwana, P. N. (2006). Some aspects of home-grown speech of francophone students: The case of clippings and blends. Language, Literature and Identity, 220-226.

Menang, T. (2005). Pidgin English and the anglophone identity in Cameroon. In International Conference on Language, Literature and Identity, University of Yaoundé (Vol. 1).

Palmer, F. R. (1981). Semantics.

Peters, P. (2004). The Cambridge guide to English usage. Ernst Klett Sprachen.

Quirk, R. (2010). A comprehensive grammar of the English language. Pearson Education India.

Rigsby, B. (1987). Indigenous language shift and maintenance in Fourth World settings. Multilingua-Journal of Cross-Cultural and Interlanguage Communication, 6(4), 359-378.

Sala, B. M. (2006). Does Cameroonian English have grammatical norms?. English Today, 22(4), 59-64.

Sala, B. M. (2006). Does Cameroonian English have grammatical norms?. English Today, 22(4), 59-64.

Seidl, J. (1989). English idioms exercises on idioms-A second edition of Idioms in practice. Oxford University Press.

Simo Bobda, A., \& Wolf, H. G. (2003). Pidgin English in Cameroon in the new millennium. Studies in African Varieties of English, Frankfurt/M.: Peter Lang, 101-117.

Suryasa, I. W., Prayoga, I. G. P. A., \& Werdistira, I. W. A. (2017). An Analysis of Students' Motivation Toward English Learning As Second Language Among Students In Pritchard English Academy (PEACE). International Journal of Social Sciences and Humanities (IJSSH), 1(2), 43-50.

Tarh, I. (2007). Pidgin English as a self-assertive language in Cameroon. Maîtrise Dissertation. Yaoundé: University of Yaoundé I. 
Todd, L. (1990). Pidgins and Creoles, new edition.

Weber, B. (2012). German colonial influences on, and representations of, Cameroon Pidgin English. Language contact in a postcolonial setting: The social and linguistic context of English and Pidgin in Cameroon, 269-296. 